\title{
Pre-Service Teachers' Perceptions of ICT and TPACK Competencies
}

\author{
Burak Demirtaş - Filiz Mumcu* \\ Received: June 13, 2020; received in revised form: November 30, 2020; \\ accepted: December 2, 2020
}

\begin{abstract}
:
Introduction: The competencies needed for information and communication technologies (ICT) integration in the teaching-learning process are related to the use of technology, pedagogical attitudes, and content planning. These qualifications are all interrelated and should not be seen separately (Becuwe et al., 2017). In this context, ICT and TPACK competencies are important for ICT integration. The standards of ISTE for educators define the ICT skills that teachers should have as designers and facilitators (International Society for Technology Education [ISTE], 2020). These standards are gathered within the framework of ICT literacy, digital literacy, and ICT competence (Tondeur et al., 2017). The concept of ICT competence discussed in this study refers to the integrated and functional use of digital knowledge, skills and attitudes (Hatlevik et al., 2015). In this study, the ICT integration competencies of pre-service teachers (PSTs) were examined as ICT competencies and TPACK competencies in terms of a range of variables. For this purpose, the following question was asked: "Is there any significant difference in the ICT integration competencies of PSTs according to a range of variables?"

Methods: This study is based on causal-comparative research. The research was conducted in the autumn term of the 2019-2020 academic year. A convenience sampling method was used. In this regard, 413 PSTs, who are students of faculties of education at ten state universities located in different cities in Turkey, participated voluntarily in the study. The "Pre-service Teachers' ICT Competencies Scale" developed by Tondeur et al. (2017) and the "TPACK-Deep Scale" developed by Kabakçı Yurdakul et al. (2012) were used to collect the data in the study. In addition to the scales, seven questions were asked about gender, grade, department, GPA, ICT course grade, owning a computer for educational purposes, and one's perceived ability to use technology. Two methods have been adopted to collect data. The first was to collect the printed forms that were completed
\end{abstract}

\footnotetext{
* Burak Demirtaş, Haydaroğlu Primary School, Eleşkirt, Ağrı, Turkey; demirtasburak65@gmail.com Filiz Mumcu, Manisa Celal Bayar University, Department of Computer Education and Instructional Technology, Manisa, Turkey; filizkuskaya@gmail.com
} 


\section{Acta Educationis Generalis \\ Volume 11, 2021, Issue 2}

in pen by the PSTs, and the second was to prepare the electronic form and deliver it to the PSTs via e-mail and social media applications and then collect the data. To analyse the data, descriptive statistics, independent samples t-test and one-way analysis of variance (ANOVA) were used.

Results: ICT and TPACK competencies of PSTs differ according to grade, having one's own computer for educational purposes, and one's perceived ability to use technology, but do not differ by gender. There is no significant difference in ICT and TPACK competencies according to the gender of PSTs. There is a significant difference in ICT and TPACK competencies according to the grade of PSTs and this difference is in favour of fourth grades. There is a significant difference in terms of ICT competencies and TPACK competencies according to computer ownership for educational purposes. This difference is in favour of PSTs who have their own computers. According to the perceived ability to use the technology of PSTs, there is a significant difference in ICT competencies and TPACK competencies. This difference is in favour of PSTs who think they can use technology at the advanced or expert level.

Discussion: In the face of constantly developing and changing technology, an important consideration is the competencies teachers and PSTs should have for ICT integration. Factors contributing to the explanation of the ICT integration process such as skills and competencies, pedagogical beliefs and self-efficacy, professional development and teacher experiences, ICT infrastructure, and access and tools are seen to have a positive effect on ICT use (Kaya \& Usluel, 2011). It has been suggested that competence and pedagogical knowledge regarding ICT integration as perceived by teachers are important when starting to integrate ICT into teaching practices (Aslan \& $\mathrm{Zu}, 2015$ ). In this study, it was found that there is a difference in ICT integration competencies of PSTs in favour of those who have their own computers and those who think they can use technology at the advanced or expert level. As the PSTs experience an increase in their perceived level of skill in their use of technology, their ICT integration competencies increase. This study also shows that PSTs' computer ownership has an impact on their education and improves their technological skills, making a difference in terms of ICT integration competencies.

Limitations: This study was limited to PSTs who studied at the faculty of education at state universities in Turkey. In addition, two scales related to ICT integration and one demographic questionnaire were used. Also, the convenience sampling method was used and the sampling was confined to 413 PSTs.

Conclusions: There is a need for educational processes that emphasise technology's educational value and enable teachers to improve themselves pedagogically and plan more effective teaching-learning processes using this pedagogical knowledge. To meet the needs of the learners of this century, teachers must first be equipped with the necessary knowledge and skills in their educational processes (Yildırım, 2000; Zhou et al., 2010). PSTs should experience this process in their teaching-learning process, 


\section{Acta Educationis Generalis \\ Volume 11, 2021, Issue 2}

and should receive training in the integration of ICT in the teachinglearning process (Çubukçu et al., 2017). Research shows that the learning experiences of PSTs in this sense and the integration of ICT with their subject areas are closely related to understanding the educational value of ICT (Mumcu \& Usluel, 2015). Academics, who take a role in teacher education, should use technology effectively in their lessons, and PSTs should experience the educational uses of technology through their education (Başal, 2015). In this sense, academics who take part in teacher education have important duties.

Key words: ICT integration, pre-service teachers, ICT competencies, TPACK competencies.

\section{Introduction}

The integration of information and communication technologies (ICT) into the teaching-learning process is a complex process involving different actors and activities, including the student, teacher, technology, school, and system (Bozdağ, 2017). Effective ICT integration is the process of adapting to technology at the individual and organisational level and transforming it into culture (Çubukçu et al., 2017). It has been observed that the studies examining the effective use and integration of ICT in the teaching-learning process in the late 1990s and early 2000s focused on describing the situation and defining the factors that hinder it. In this sense, one of the most important studies was done by Ertmer (1999). Ertmer (1999) defined obstacles as the first and second level in ICT integration. First-level obstacles were called external barriers, such as access to technology, and the school's level of support; second-level barriers were called internal barriers related to the knowledge, beliefs and attitudes towards technology that needed improvement. Today, technical problems such as the infrastructure and hardware of schools, which are called external barriers, have been overcome, and an improvement has been achieved in teachers' and students' access to technology. However, it does not seem possible for teachers to use this technology in the classroom. Research shows that even experienced teachers do not have the necessary competence to integrate ICT into the teaching-learning process, although they have the necessary skills related to ICT (Aslan \& $\mathrm{Zu}, 2015$ ). There is a need for a change in the knowledge, beliefs, and attitudes of teachers about ICT integration. A multidimensional effort is needed to deal with internal barriers, including teacher competencies (Nelson \& Hawk, 2020).

ICT is only a tool, and the fact that it exists in the classroom does not mean that ICT is automatically used effectively in the teaching-learning process (Nelson \& Hawk, 2020). Similarly, teachers' perceptions about using ICT should not be taken as an indication that they effectively use ICT in the teaching-learning 


\section{Acta Educationis Generalis \\ Volume 11, 2021, Issue 2}

process; that is, they integrate ICT (Mumcu, 2017). It should be understood from the integration of ICT that the borders between ICT and learning and teaching disappear and that ICT is an invisible but significant part of the process. ICT integration should support students to construct knowledge by completing meaningful and realistic tasks.

Research carried out within the last decade indicates that teachers should aim for effective use of their ICT knowledge and skills in teaching-learning processes (Angeli \& Valanides, 2009), and teachers should have the necessary ICT competencies to demonstrate the transformative effect of ICT in education (Göktaş, Yıldırım, \& Yıldırım, 2009). Because changes in technology force schools to integrate innovative technologies into the teaching-learning process, teachers are expected to have digital skills and competencies to use effectively in the teaching-learning process (Kozma, 2010). In this study, ICT integration competencies of pre-service teachers (PSTs) were examined in terms of a range of variables and evaluated within the scope of teacher education.

\section{Theoretical background}

\subsection{The role of teachers in ICT integration}

The obstacles defined in the integration of ICT into the teaching-learning process are mostly encountered by teachers (Tosuntaş, Çubukçu, \& İnci, 2019). Studies examining teachers' use of technology demonstrate that teachers' use of ICT for teaching purposes, and teachers' attitudes, perceptions, beliefs, and views on ICT usage are the most studied topics (Kurtoğlu \& Seferoğlu, 2013). Students and teachers are the main actors of the teaching-learning process, especially in the classroom. Teachers also think that their role is vital in the ICT integration process (Keleş \& Güntepe, 2018). Thus, the studies have focused on teachers' classroom practices and the difficulties they experience in this process. At this point, it is crucial to examine how teachers use ICT in the teachinglearning process.

Teachers mostly use ICT applications for personal and managerial purposes (Mumcu \& Usluel, 2010) and mostly use word-processor programmes and Internet applications (Usluel, Mumcu, \& Demiraslan, 2007). Teachers have been successful in basic computer applications, such as word processing, but they have failed in applications such as educational software; the teachers, therefore, seem to have important deficiencies in ICT applications (Cüre \& Özdener, 2008). Although teachers' skills in their use of ICT resources and applications are important, having competencies related to ICT integration is also important in terms of the use of technology in teaching (Çırak \& Demir, 2014). In addition to ICT literacy, teachers need to know how to use ICT effectively in education (Çam \& Saltan, 2019) and support it with appropriate pedagogical approaches (Ersoy, Yurdakul, \& Ceylan, 2016; Şahin et al., 2013). In this context, there are significant differences in ICT integration according to the teachers' training in 
ICT (Usluel, Mumcu, \& Demiraslan, 2007). It has been suggested that teacher education programmes should be revised to develop the technological and pedagogical knowledge and skills of PSTs (Başal, 2015).

Providing PSTs with training in ICT integration facilitates changes in their knowledge and skills in implementing ICT integration. In the study conducted by Mumcu (2017), PSTs' concerns about ICT integration and their beliefs about ICT integration obstacles disappeared due to ICT integration training. Also, their thoughts about ICT usage in the teaching-learning process shifted from teachercentred understanding to student-centred understanding. Studies have demonstrated that teachers and PSTs who have such training have improved their ICT integration skills in overcoming significant obstacles such as classroom management (Çelik, Hebebci, \& Şahin, 2016; Güneş \& Buluç, 2018). Teachers should have the necessary knowledge and skills to ensure ICT integration and they should be able to design appropriate learning environments that will support their students' high-level thinking skills such as problemsolving and creative thinking, encourage their students to have a positive attitude in this regard, and ensure cooperation among students. In this respect, teacher education institutions are expected to equip PSTs with the appropriate knowledge and skills (Biriş̧̧i \& Kul, 2018).

\subsection{ICT integration competencies of PSTs}

In integrating ICT in the teaching-learning process, it is essential to plan the process from preparation and implementation to measurement and evaluation (Haşlaman, Mumcu, \& Usluel, 2007; Uslu \& Usluel, 2020). Within the scope of ICT integration competencies, teachers are expected to plan lessons that include the use of ICT and should consider their students' needs and differences when they prepare their learning resources (Sar1 et al., 2016). To do this, the teacher should have ICT competencies and technological pedagogical content knowledge competencies, as well as ICT literacy. Teachers should be provided with the necessary competencies in this sense (Atalay \& Anagün, 2014). Teachers need professional development in technology, pedagogy and content interaction, and their experience, education, and training levels in ICT integration affect their competencies in this regard (Çrak \& Demir, 2014). It has been demonstrated that teachers' experiences and ideas gained during their training in ICT integration have a positive effect on their ICT competencies, resulting in a positive relationship between ICT application successes and teachers' attitudes towards ICT (Cüre \& Özdener, 2018). In this regard, the technological pedagogical content knowledge (TPACK) model (Mishra \& Koehler, 2006) is a frequently used teacher education model.

The TPACK model appears to be the most popular model used to integrate ICT into the learning-teaching process (Usluel, Özmen, \& Çelen, 2015). This model can be explained briefly as the addition of technological knowledge to the pedagogical content knowledge model developed by Shulman (Figure 1). 


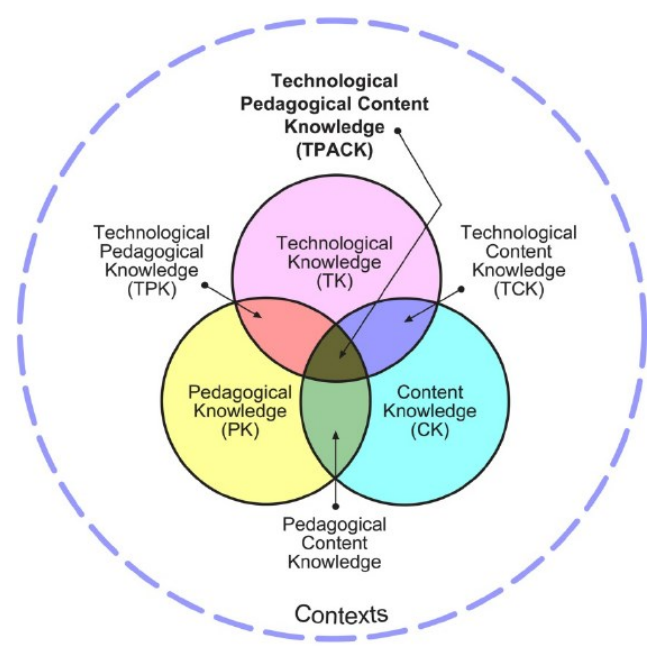

Figure 1. Technological Pedagogical Content Knowledge (TPACK) Model (Mishra \& Koehler, 2006).

The three main knowledge areas of the TPACK model are technological knowledge, pedagogical knowledge, and content knowledge. Pedagogical content knowledge, technological pedagogical knowledge, technological content knowledge, and technological pedagogical content knowledge, which are the intersections of the three main knowledge areas, explain the sub-dimensions. At the centre of the TPACK model is the integrated form of the relationship between content, pedagogy, and technology knowledge. Content knowledge is the subject field that needs to be delivered to the student during the teachinglearning process. Pedagogical knowledge is about learning and teaching methods and techniques and practices. It covers all the instructional intentions, values and goals of the teacher. Pedagogical content knowledge represents the teacher's strategies to evaluate the teaching of the subjects and the students' learning about these topics. In short, it is the conversion of content knowledge into teaching activities. Defining technological knowledge is quite tricky because it is more variable than the other two core areas of knowledge. In short, it contains information on how to use technology. Technological content knowledge is an understanding of the effect of technology on content and the development of appropriate technological tools for educational purposes. It is an understanding of the way technology and content influence and limit one another. Technological pedagogical knowledge is the answer to how technology can be used to change the teaching-learning process. It can be taken as an extension of general pedagogical knowledge about knowing how technology can support specific classroom pedagogical strategies. It is not correct to present a single-use option for technology. Technological pedagogical content knowledge includes 
the dynamic relationship between technology, pedagogy and content information necessary for teachers to integrate technology into the teaching-learning process. TPACK, which defines the relationship between technology, content and pedagogy for effective technology integration, represents the entire process.

As TPACK is seen as a dynamic relationship between technology, pedagogy and content, teachers are expected to evaluate technology, pedagogy and content knowledge as a whole in the process of integrating ICT (Özkara, Konokman, \& Yelken, 2018). TPACK is defined as all of the knowledge required for teachers involved to present the content they handle with appropriate pedagogy and technology (Ersoy, Yurdakul, \& Ceylan, 2016).

The way teachers use technology in teaching and their competencies related to technology affect their perceptions and thoughts about the interaction between technology, content, and pedagogy; it is essential, therefore, that teachers receive professional development in this sphere (Çırak \& Demir, 2014). Thus, it is recommended to use the model to create experiences for ICT integration and improve the development of this knowledge, especially in teacher education (Çam \& Saltan, 2019). It has been demonstrated in studies examining the TPACK competencies of PSTs that they consider themselves sufficiently equipped with pedagogical knowledge, but they are undecided regarding their competencies in other sub-dimensions (Çil \& Çakmak, 2014).

The competencies needed for ICT integration in the teaching-learning process are related to technology usage, pedagogical attitudes, and content planning. These qualifications are all interrelated and should not be seen separately (Becuwe et al., 2017). In this context, ICT competencies and TPACK competencies are essential for ICT integration. The standards of ISTE for educators define the ICT skills that teachers should have as designers and facilitators (International Society for Technology Education [ISTE], 2020). These standards are gathered within the framework of ICT literacy, digital literacy, and ICT competence (Tondeur et al., 2017). The concept of "ICT competence" discussed in this study refers to the integrated and functional use of digital knowledge, skills, and attitudes (Hatlevik et al., 2015).

\subsection{Research problem}

There is a demand for teachers who have high-level ICT competencies and who make effective pedagogical use of ICT, and there are efforts to increase teachers' ICT integration competencies nationally and internationally. In Europe, the ICT competencies and challenges of educators have been described in the European Digital Competence Framework for Educators (DigComEdu) (Redecker, 2017). The framework is a scientific structure that describes what it means for educators to be digitally competent. It provides a general frame of reference to support the development of educator-specific digital competencies in Europe. The Turkish Ministry of National Education (MoNE) published The Generic Teacher Competencies report. In the report, the ability to use ICT effectively in 


\section{Acta Educationis Generalis \\ Volume 11, 2021, Issue 2}

the teaching-learning process has been identified as one of the fundamental skills that every teacher should have (MoNE, 2017). Within the scope of "Digital Content and Skill Assisted Transformation in Learning Processes", two goals for digitalisation in education are set:

1. Ecosystem building for the development of digital content and skills.

2. Content development and teacher training for the development of digital skills.

Under these competencies defined by MoNE, the Higher Education Council (HEC) of Turkey made notable changes in teacher education programmes. One of the aims of the new curriculum is that PSTs can demonstrate their knowledge and skills acquired during their education in front of their classmates and a real classroom environment and use ICT effectively in the teaching-learning process within the scope of ICT related courses (HEC, 2018).

In this study, ICT integration competencies of PSTs were examined as ICT competencies and TPACK competencies in terms of a range of variables. For this purpose, the following questions were asked:

- Is there any significant difference in the ICT integration competencies of PSTs according to a range of variables?

i. Is there any significant difference in the ICT integration competencies of PSTs by gender?

ii. Is there any significant difference in the ICT integration competencies of PSTs by grade?

iii. Is there any significant difference in the ICT integration competencies of PSTs according to having one's own computer for educational purposes?

iv. Is there any significant difference in the ICT integration competencies of PSTs according to one's perceived ability to use technology?

\section{Methodology}

\subsection{Research model}

This study is causal-comparative research. Büyüköztürk (2002) defines the causal-comparative research design as a type of research that determines the causes of an emerging/existing situation or event, the variables affecting these causes, or the consequences of an impact. The researchers' goal is to compare two or more groups to determine whether the independent variables affect the outcome or dependent variable.

\subsection{Study group}

A convenience sampling method was used in sampling. In this regard, 413 PSTs, who are students of education faculties at ten state universities located in different cities in Turkey, participated voluntarily in the study. Demographic data related to the study group are given in Table 1. 
Table 1

Demographic data of the study group

\begin{tabular}{|c|c|c|c|}
\hline Variable & Group & $\underline{N}$ & $\underline{\%}$ \\
\hline \multirow[t]{2}{*}{$\overline{\text { Gender }}$} & $\overline{\text { Female }}$ & $2 \overline{7} 8$ & $6 \overline{7.3}$ \\
\hline & Male & 135 & 32.7 \\
\hline \multirow[t]{4}{*}{ Grade } & $1^{\text {st }}$ grade & 129 & 31.2 \\
\hline & $2^{\text {nd }}$ grade & 74 & 17.9 \\
\hline & $3^{\text {rd }}$ grade & 60 & 14.5 \\
\hline & $4^{\text {th }}$ grade & 150 & 36.3 \\
\hline \multirow[t]{9}{*}{ Department } & Computer education & 105 & 25.4 \\
\hline & $\begin{array}{l}\text { Psychological counselling and } \\
\text { guidance }\end{array}$ & 55 & 13.3 \\
\hline & Pre-school education & 65 & 15.8 \\
\hline & Turkish education & 39 & 9.4 \\
\hline & Social studies education & 36 & 8.7 \\
\hline & Elementary mathematics education & 54 & 13.1 \\
\hline & Primary education & 21 & 5.1 \\
\hline & Science education & 15 & 3.6 \\
\hline & Music education & 23 & 5.6 \\
\hline Academic Grade Point & $0.00-1.50$ & 8 & 1.9 \\
\hline \multirow[t]{5}{*}{ Average (GPA) } & $1.51-2.00$ & 7 & 1.7 \\
\hline & $2.01-2.50$ & 74 & 17.9 \\
\hline & $2.51-3.00$ & 154 & 37.3 \\
\hline & $3.01-3.50$ & 133 & 32.2 \\
\hline & $3.51-4.00$ & 37 & 9.0 \\
\hline \multirow[t]{6}{*}{ ICT Course Grade } & $0-50$ point & 8 & 1.9 \\
\hline & $51-60$ point & 56 & 13.6 \\
\hline & $61-70$ point & 101 & 24.5 \\
\hline & $71-80$ point & 88 & 21.3 \\
\hline & $81-90$ point & 80 & 19.4 \\
\hline & $91-100$ point & 80 & 19.4 \\
\hline \multirow{2}{*}{$\begin{array}{l}\text { Ownership of a } \\
\text { computer for } \\
\text { educational purposes }\end{array}$} & None & 116 & 28.1 \\
\hline & Yes & 297 & 71.9 \\
\hline \multirow{4}{*}{$\begin{array}{l}\text { Perceived ability to use } \\
\text { technology }\end{array}$} & Basic level & 66 & 16.0 \\
\hline & Intermediate level & 240 & 58.1 \\
\hline & Advanced level & 90 & 21.8 \\
\hline & Expert level & 17 & 4.1 \\
\hline Total & & 413 & 100.0 \\
\hline
\end{tabular}

When Table 1 is examined, $67.3 \%$ of the PSTs are female and $32.7 \%$ are male. In the study group, the PSTs studying computer education, pre-school education, psychological counselling and guidance, and elementary mathematics education constitute the majority. When the distribution of the PSTs by grade is analysed, 129 (31.2\%) are in the first grade, $74(17.9 \%)$ are in the second grade, $60(14.5 \%)$ are in the third grade, and $150(36.3 \%)$ are in the fourth grade. $78.5 \%$ of the PSTs have an overall GPA above 2.51, 
and $60.1 \%$ of them have an overall ICT course grade above 71 points. $71.9 \%$ of the PSTs have their own computer to use for their education. It has been determined that $25.9 \%$ of PSTs see themselves at an advanced and expert level in using technology.

\subsection{Data collection tools}

The "Pre-service Teachers' ICT Competencies Scale" developed by Tondeur et al. (2017) and the "TPACK-Deep Scale" developed by Kabakçı Yurdakul et al. (2012) were used to collect the data in the study. In addition to the scales, seven questions were asked about gender, grade, department, GPA, ICT course grade, having one's own computer for educational purposes, and one's perceived ability to use technology.

\subsubsection{Pre-Service Teachers' ICT Competencies Scale}

Tondeur et al. (2017) developed the scale to measure the competencies that PSTs should have to integrate ICT into teaching-learning processes. The scale was adapted into Turkish by Mumcu, Uslu, and Geriş (2018). Each item in the scale is presented for one of three dimensions of ICT competencies: (1) to educate pupils to become ICT competent, (2) to support and strengthen learning and development processes utilising ICT, and (3) to organise ICT appropriately in the learning environment. The scale consists of two factors and 19 items:

- Competencies to support pupils for ICT use in class: ICT Competence Pupil Use (ICTC-PU);

- Competencies to use ICT for Instructional Design: ICT Competence Instructional Design (ICTC-ID).

The 11 items in the ICTC-PU factor are designed to measure the competence of PSTs to educate pupils in the use of ICT for their learning processes. The eight items included in the ICTC-ID factor are designed to measure the ability of PSTs to use ICT to support and strengthen their teaching practices. As such, the items in ICTC-ID are combined with two theoretical dimensions.

The items are 5-point Likert type and the answers are expressed as $1=$ "I totally disagree", 5 = "I totally agree". The original study found that the two-factor scale explained $56.3 \%$ of the total variance. In the adaptation study of the scale to Turkish by Mumcu, Uslu, and Geriş (2018), confirmatory factor analysis was performed on the data collected from 422 PSTs. As a result of DFA, the measurement model's compliance with the data was tested with a chi-square fit test, RMSEA, S-RMR, GFI, CFI, and NFI. According to the confirmatory factor analysis findings, the fit indices showed an acceptable/perfect fit. For reliability studies, a Cronbach $\alpha$ internal consistency coefficient and corrected item-total correlations were calculated to examine item discrimination. The Cronbach $\alpha$ internal consistency coefficient of the Turkish form of the scale was calculated as .953 . 


\subsubsection{TPACK-Deep Scale}

Kabakçı Yurdakul et al. (2012) developed the scale to determine the competency levels of PSTs for techno-pedagogical education. The scale consists of 33 items and displays a four-factor structure: design, exertion, ethics, and proficiency. Items are of the 5-point Likert type, and the answers are expressed as 1= "I absolutely cannot do it", to $5=$ "I can definitely do it".

The "design" factor, which is the first factor of the scale, refers to the teaching design competencies that will enrich the teaching process by blending the technology and pedagogy knowledge suitable for the content to be taught. There are a total of ten items in this factor. The second factor of the scale is "exertion". This factor refers to the PSTs' competence in using technology to conduct the teaching process designed for the subject area, and their ability to measure and evaluate the effectiveness of the process. There are a total of 12 items in this factor. The third factor of the scale is "ethics". This factor refers to the competencies of PSTs in teaching ethics, as well as copyright, intellectual property, accuracy of information, confidentiality, and security in technology ethics. There are six items in this factor. The last factor of the scale is "proficiency". This factor includes producing suggestions for solving problems related to the subject area, the teaching process, and technology, choosing the appropriate solution, and leading the environment to integrate technology with content and pedagogy. There are five items in this factor.

Exploratory factor analysis was performed to examine the construct validity of the scale. It was determined that the scale consisting of 33 items had a fourfactor structure in its final form, the explained variance was $58.591 \%$ and the factor load values were between .562 and .776. The internal consistency coefficient for 33 items was calculated as $\alpha=.96$. Internal consistencies in terms of the factors forming the scale were calculated as $\alpha=.91$ for the "design" factor, $\alpha=.92$ for the "exertion" factor, $\alpha=.87$ for the "ethics" factor and $\alpha=$ .86 for "proficiency".

\subsection{Data collection}

The research was conducted in the autumn term of the 2019-2020 academic year. Two methods have been adopted to collect data. The first was to collect the printed forms that were completed in pen by the PSTs, and the second was to prepare the electronic form and deliver it to the PSTs via e-mail and social media applications and then collect the data. The Google Forms application was used for the second data collection method.

\subsection{Data analysis}

Independent samples t-test and one-way analysis of variance (ANOVA) were used to test the significance of the difference between the means, and descriptive statistics were also used for the research. The significance level was taken as $\alpha=$ 0.05 for independent samples t-test and ANOVA. For ANOVA, the Bonferroni 
test was used to find the difference between the groups. An SPSS programme was used for analyses.

\section{Results}

ICT integration competence levels of PSTs in terms of ICT and TPACK competencies have been examined by gender, grade, having one's own computer for educational purposes, and one's perceived ability to use technology. For this purpose:

- Analysis was carried out to establish whether there was a significant difference between ICT competence levels of PSTs in terms of ICTC-PU and ICTC-ID. To this end, independent samples t-test and ANOVA were conducted.

- Analysis was carried out to establish whether there was a significant difference between TPACK competence levels of PSTs in terms of design, exertion, ethics, and proficiency. For this purpose, independent samples t-test and ANOVA were conducted.

The study results and the findings are given below according to gender, grade, having one's own computer for educational purposes, and one's perceived ability to use technology.

\subsection{ICT integration competencies of PSTs by gender}

The independent samples t-test was conducted to examine whether there is a significant difference between the ICT integration competence levels of PSTs according to their gender. The findings of the analyses are given in Table 2 and Table 3.

Table 2

Findings of independent samples t-test analysis for ICT competencies by gender

\begin{tabular}{lllccccc}
\hline \multirow{2}{*}{ ICTC-PU } & Groups & $\underline{N}$ & $\underline{\underline{x}}$ & $\underline{\underline{S D}}$ & $\underline{t}$ & $\underline{D F}$ & $\underline{p}$ \\
& Male & 278 & 42.82 & 9.051 & - & 411 & 0.76 \\
ICTC-ID & Female & 135 & 43.11 & 8.880 & 0.305 & & 1 \\
& Male & 135 & 30.19 & 6.659 & - & 411 & 0.28 \\
& & & 30.94 & 6.814 & 1.071 & & 5 \\
\hline
\end{tabular}

As seen in Table 2, the mean of the competence to support students for ICT use in the classroom (ICTC-PU) of 278 female PSTs is 42.82 and that of 135 male PSTs is 43.11. The mean of the competence to use ICT for instructional design (ICTC-ID) of female PSTs is 30.19 and of that male PSTs is 30.94. As a result of independent samples t-test analysis, there is no significant difference at the level of .05 between the ICT competencies of PSTs by gender (ICTC-PU $[\mathrm{t}(411)=-0.305, \mathrm{p}>0.05]$ and ICTC-ID $[\mathrm{t}(411)=-1.071, \mathrm{p}>0.05])$. 


\section{Acta Educationis Generalis \\ Volume 11, 2021, Issue 2}

Table 3

Findings of independent samples t-test analysis for TPACK competencies by gender

\begin{tabular}{lllllclc}
\hline \multirow{2}{*}{ Design } & Groups & $\underline{\underline{N}}$ & $\underline{\underline{x}}$ & $\underline{S D}$ & $\underline{\underline{t}}$ & $\underline{\underline{D}}$ & $\underline{\underline{p}}$ \\
& Female & 278 & 38.48 & 6.941 & -0.215 & 411 & 0.830 \\
\multirow{2}{*}{ Exertion } & Male & 135 & 38.64 & 8.161 & & & \\
& Female & 278 & 47.38 & 8.694 & 0.799 & 411 & 0.425 \\
& Male & 135 & 46.61 & 9.878 & & & \\
\multirow{2}{*}{ Proficsiency } & Female & 278 & 23.75 & 4.444 & 0.795 & 411 & 0.427 \\
& Male & 135 & 23.37 & 4.709 & & & \\
& Female & 278 & 18.19 & 3.891 & -1.215 & 411 & 0.225 \\
& Male & 135 & 18.70 & 4.206 & & & \\
\hline
\end{tabular}

As seen in Table 3, as a result of independent samples t-test analysis, there is no significant difference at the level of .05 between the TPACK competencies of PSTs by gender (Design [ $\mathrm{t}(411)=-0.215, \mathrm{p}>0.05]$; Exertion $[\mathrm{t}(411)=0.799$, $\mathrm{p}>0.05]$; Ethics [t(411) $=0.795, \mathrm{p}>0.05]$; Proficiency [t(411)=-1.215, $\mathrm{p}>0.05])$.

\subsection{ICT integration competencies of PSTs by grade}

ANOVA was conducted to examine whether there is a significant difference between the ICT integration competence levels of PSTs according to their grades. The findings of the analyses are given in Table 4 and Table 5.

Table 4

Findings of ANOVA for ICT competencies by grade

\begin{tabular}{|c|c|c|c|c|c|c|c|}
\hline & $\frac{\text { Source of }}{\text { variance }}$ & $\frac{\text { Sum of }}{\text { squares }}$ & $\underline{D F}$ & $\frac{\text { Mean }}{\text { squares }}$ & $\underline{F}$ & $\underline{p}$ & $\underline{\text { Bonferroni }}$ \\
\hline \multirow{3}{*}{ ICTC-PU } & $\begin{array}{l}\text { Between } \\
\text { grouns }\end{array}$ & 1633.404 & 3 & 544.468 & \multirow{3}{*}{7.040} & \multirow[t]{3}{*}{$.000^{*}$} & \multirow{3}{*}{$\begin{array}{l}1-3 \\
1-4\end{array}$} \\
\hline & In groups & 31633.797 & 409 & 77.344 & & & \\
\hline & Total & 33267.201 & 412 & & & & \\
\hline \multirow{2}{*}{ ICTC-ID } & $\begin{array}{l}\text { Between } \\
\text { groups }\end{array}$ & 1119.670 & 3 & 373.223 & \multirow{2}{*}{8.755} & \multirow{2}{*}{$.000^{*}$} & \multirow{2}{*}{$\begin{array}{l}1-3 \\
1-4\end{array}$} \\
\hline & $\begin{array}{l}\text { In groups } \\
\text { Total }\end{array}$ & $\begin{array}{l}17435.749 \\
18555.419\end{array}$ & $\begin{array}{l}409 \\
412\end{array}$ & 42.630 & & & \\
\hline
\end{tabular}

According to Table 4, there is a significant difference between:

- the competence to support students for ICT use in the classroom (ICTC-PU) of PSTs by grade $(\mathrm{F}=7.040, \mathrm{p}<=0.05)$, and

- the competence to use ICT for instructional design (ICTC-ID) of PSTs by grade $(\mathrm{F}=8.755, \mathrm{p}<=0.05)$. 
The Bonferroni test was conducted to find out which groups have a difference in means. It was found that ICT competencies of PSTs who attend to third and fourth grades are higher than PSTs who attend first grade in terms of ICTC-PU and ICTC-ID.

\section{Table 5}

\begin{tabular}{|c|c|c|c|c|c|c|c|}
\hline & $\frac{\text { Source of }}{\text { variance }}$ & $\begin{array}{l}\frac{\text { Sum of }}{\text { squares }} \\
\text { squat }\end{array}$ & $\underline{D F}$ & $\begin{array}{l}\text { Mean } \\
\text { squares }\end{array}$ & $\underline{F}$ & $\underline{p}$ & $\underline{\text { Bonferroni }}$ \\
\hline \multirow{2}{*}{ Design } & $\begin{array}{l}\text { Between } \\
\text { groups }\end{array}$ & 1008.656 & 3 & 336.219 & \multirow{2}{*}{6.468} & \multirow{2}{*}{$.000^{*}$} & \multirow{2}{*}{$\begin{array}{l}1-3 \\
1-4\end{array}$} \\
\hline & $\begin{array}{l}\text { In groups } \\
\text { Total }\end{array}$ & $\begin{array}{ll}21 & 262.153 \\
22 & 270.809\end{array}$ & $\begin{array}{l}409 \\
412\end{array}$ & 51.986 & & & \\
\hline \multirow{3}{*}{ Exertion } & $\begin{array}{l}\text { Between } \\
\text { groups }\end{array}$ & 1172.859 & 3 & 390.953 & \multirow{3}{*}{4.861} & \multirow{3}{*}{$.002 *$} & \multirow{3}{*}{$1-4$} \\
\hline & In groups & 32893.340 & 409 & 80.424 & & & \\
\hline & Total & 34066.199 & 412 & & & & \\
\hline \multirow{2}{*}{ Ethics } & $\begin{array}{l}\text { Between } \\
\text { groups }\end{array}$ & 259.205 & 3 & 86.402 & \multirow{2}{*}{4.312} & \multirow{2}{*}{$.005^{*}$} & \multirow{2}{*}{$1-4$} \\
\hline & $\begin{array}{l}\text { In groups } \\
\text { Total }\end{array}$ & $\begin{array}{l}8195.623 \\
8454.828\end{array}$ & $\begin{array}{l}409 \\
412\end{array}$ & 20.038 & & & \\
\hline \multirow{2}{*}{ Proficiency } & $\begin{array}{l}\text { Between } \\
\text { groups }\end{array}$ & 272.030 & 3 & 90.677 & \multirow{2}{*}{5.872} & \multirow{2}{*}{$.001 *$} & \multirow{2}{*}{$\begin{array}{l}1-3 \\
1-4\end{array}$} \\
\hline & $\begin{array}{l}\text { In groups } \\
\text { Total }\end{array}$ & $\begin{array}{l}6316.358 \\
6588.387\end{array}$ & $\begin{array}{l}409 \\
412\end{array}$ & 15.443 & & & \\
\hline
\end{tabular}

\footnotetext{
${ }^{*} \alpha=0.05 ; 1: 1$ st grade $2: 2$ nd grade $3: 3$ rd grade $4: 4$ th grade
}

According to Table 5, there is a significant difference between TPACK competencies of PSTs in terms of design, exertion, ethics and proficiency by grade, namely:

- Design that indicates the instructional design competencies that will enrich the teaching process by blending the PSTs' technology and pedagogy knowledge appropriate to the content to be taught $(\mathrm{F}=6.468, \mathrm{p}<=0.05)$,

- Exertion expressing the competence of using technology in the implementation of the teaching process designed for the subject area and competence in measuring and evaluating the effectiveness of the process $(\mathrm{F}=4.861, \mathrm{p}<=0.05)$,

- Ethical issues addressing the issues of copyright, intellectual property, accuracy, confidentiality and security of technology ethics, as well as teaching professional ethics $(\mathrm{F}=4.312, \mathrm{p}<=0.05)$, and

- Proficiency in the ability to produce suggestions and to lead the environment in the integration of technology with content and pedagogy by specialising in the teaching profession $(\mathrm{F}=5.872, \mathrm{p}<=0.05)$. 
The Bonferroni test was conducted to find out which groups have a difference in means. It was found that the design, exertion, ethics, and proficiency competencies of PSTs who attend to fourth grades are higher than first grade PSTs, and design and proficiency competencies of PSTs who attend to third grades are higher than first grade PSTs.

\subsection{ICT integration competencies of PSTs according to having one's own computer for educational purposes}

The independent samples t-test was conducted to examine whether there is a significant difference between the ICT competence levels of PSTs according to computer ownership for educational purposes. The findings are given in Table 6.

Table 6

Findings of independent samples t-test analysis for ICT competencies according to having one's own computer for educational purposes

\begin{tabular}{lllccccc}
\hline & Groups & $\underline{N}$ & $\underline{\bar{x}}$ & $\underline{\underline{S D}}$ & $\underline{t}$ & $\underline{D F}$ & $\underline{p}$ \\
ICTC-PU & None & 116 & 39.96 & 8.912 & - & 411 & $0.000^{*}$ \\
& Yes & 297 & 44.07 & 8.761 & 4.271 & & \\
ICTC-ID & None & 116 & 27.73 & 6.159 & - & 411 & $0.000^{*}$ \\
& Yes & 297 & 31.49 & 6.631 & 5.275 & &
\end{tabular}

As seen in Table 6, PSTs' ICT competencies to support students for ICT use in the classroom (ICTC-PU) [ $\mathrm{t}(411)=-4.271, \mathrm{p}>0.05]$ and to use ICT for instructional design (ICTC-ID) $[\mathrm{t}(411)=5.275, \mathrm{p}>0.05]$ differ significantly according to computer ownership for educational purposes. ICT competencies of PSTs who own computers are significantly higher than PSTs who do not.

To examine whether there is a significant difference between TPACK competencies of PSTs in terms of design, exertion, ethics and proficiency according to computer ownership for educational purposes, independent samples t-test was conducted. The findings are given in Table 7.

Table 7

Findings of independent samples t-test analysis for TPACK competencies according to having one's own computer for educational purposes

\begin{tabular}{|c|c|c|c|c|c|c|c|}
\hline & Groups & $\underline{N}$ & $\underline{\bar{x}}$ & $\underline{S D}$ & $\underline{t}$ & $\underline{D F}$ & $\underline{p}$ \\
\hline \multirow[b]{2}{*}{ Design } & None & 116 & 36.28 & 6.580 & & \multirow{2}{*}{411} & \multirow{2}{*}{$.000^{*}$} \\
\hline & Yes & 297 & 39.41 & 7.461 & 3.952 & & \\
\hline \multirow{2}{*}{ Exertion } & None & 116 & 44.00 & 8.672 & 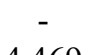 & \multirow[t]{2}{*}{411} & \multirow[t]{2}{*}{$.000^{*}$} \\
\hline & Yes & 297 & 48.35 & 8.974 & 4.469 & & \\
\hline Ethics & $\begin{array}{l}\text { None } \\
\text { Yes }\end{array}$ & $\begin{array}{l}116 \\
297\end{array}$ & $\begin{array}{l}22.28 \\
24.15\end{array}$ & $\begin{array}{l}4.321 \\
4.508\end{array}$ & $\begin{array}{c}- \\
3.844\end{array}$ & 411 & $.000^{*}$ \\
\hline
\end{tabular}




\begin{tabular}{lllllcll}
\hline \multirow{2}{*}{ Proficiency } & None & 116 & 17.09 & 3.732 & - & \multirow{2}{*}{411} & \multirow{2}{*}{$000^{*}$} \\
& Yes & 297 & 18.85 & 3.998 & 4.073 & & \\
\hline$* \alpha=0.05$ & & & & &
\end{tabular}

As seen in Table 7, TPACK competencies of PSTs differ significantly in terms of design, exertion, ethics and proficiency according to computer ownership for educational purposes. The TPACK competence level of PSTs who have their own computers is found to be significantly higher than that of PSTs who have not $($ design $[\mathrm{t}(411)=-3.952, \mathrm{p}<0.05)$; exertion $[\mathrm{t}(411)=-4.469, \mathrm{p}<0.05]$; ethics $[\mathrm{t}(411)=-3-844, \mathrm{p}<0.05]$; proficiency $[\mathrm{t}(411)=-4.073, \mathrm{p}<0.05])$.

\subsection{ICT integration competencies of PSTs according to one's perceived ability} to use technology

ANOVA was conducted to examine whether there is a significant difference in the ICT integration competence level according to how PSTs perceive their ability to use technology. The findings of the analyses are given in Table 8 and Table 9.

Table 8

Findings of ANOVA for ICT competencies according to one's perceived ability to use technology

\begin{tabular}{|c|c|c|c|c|c|c|c|}
\hline & $\frac{\text { Source of }}{\text { variance }}$ & $\begin{array}{l}\text { Sum of } \\
\text { squares }\end{array}$ & $\underline{D F}$ & $\underline{\text { Mean }}$ & $\underline{F}$ & $\underline{p}$ & Bonferroni \\
\hline \multirow{3}{*}{ ICTC-PU } & Between & 2985.324 & 3 & 995.108 & \multirow{3}{*}{13.440} & \multirow{3}{*}{$.000 *$} & $1-2$ \\
\hline & In groups & 30281.877 & 409 & 74.039 & & & $1-3$ \\
\hline & Total & 33267.201 & 412 & & & & \\
\hline \multirow{3}{*}{ ICTC-ID } & $\begin{array}{l}\text { Between } \\
\text { groups }\end{array}$ & 2107.613 & 3 & 702.538 & \multirow{3}{*}{17.470} & \multirow{3}{*}{$.000^{*}$} & $\begin{array}{l}1-2 \\
1-3\end{array}$ \\
\hline & In groups & 16447.806 & 409 & 40.215 & & & $1-4$ \\
\hline & Total & 18555.419 & 412 & & & & $\begin{array}{l}2-3 \\
2-4\end{array}$ \\
\hline
\end{tabular}

${ }^{*} \alpha=0.05 ; 1$ : Basic level 2: Intermediate level 3: Advanced level 4: Expert level

As seen in Table 8:

- There is a significant difference in the competence of PSTs to support students for ICT use in the classroom (ICTC-PU) according to how PSTs perceive their ability to use technology $(\mathrm{F}=13.440, \mathrm{p}<0.05)$. The findings of the Bonferroni test showed that the ICTC-PU competencies of PSTs who perceive their technology use as being at intermediate, advanced or expert level are higher than PSTs who perceive their technology use as being at a basic level. 
- There is a significant difference in the competence of PSTs to use ICT for instructional design (ICTC-ID) according to their perception of their ability to use technology $(\mathrm{F}=17.470, \mathrm{p}<0.05)$. The findings of the Bonferroni test showed that the ICTC-ID competencies of PSTs who perceive their technology use as being at advanced or expert level are higher than PSTs who perceive their technology use as being at a basic or intermediate level.

Table 9

Findings of ANOVA for TPACK competencies according to one's perceived ability to use technology

\begin{tabular}{|c|c|c|c|c|c|c|c|}
\hline & $\frac{\text { Source of }}{\text { variance }}$ & $\begin{array}{l}\frac{\text { Sum of }}{\text { squares }} \\
\text { squn }\end{array}$ & $\underline{D F}$ & $\frac{\text { Mean }}{\text { squares }}$ & $\underline{F}$ & $\underline{p}$ & Bonferroni \\
\hline \multirow{3}{*}{ Design } & $\begin{array}{l}\text { Between } \\
\text { groups }\end{array}$ & 3301.169 & 3 & 1100.390 & & & $\begin{array}{l}1-2 \\
1-3\end{array}$ \\
\hline & In groups & 18969.639 & 409 & 46.381 & 23.725 & $.000 *$ & $1-4$ \\
\hline & Total & 22270.809 & 412 & & & & $\begin{array}{l}2-3 \\
2-4\end{array}$ \\
\hline \multirow{3}{*}{ Exertion } & $\begin{array}{l}\text { Between } \\
\text { groups }\end{array}$ & 4701.366 & 3 & 1567.122 & & & $\begin{array}{l}1-2 \\
1-3\end{array}$ \\
\hline & In groups & 29364.832 & 409 & 71.797 & 21.827 & $.000^{*}$ & $1-4$ \\
\hline & Total & 34066.199 & 412 & & & & $\begin{array}{l}2-3 \\
2-4\end{array}$ \\
\hline \multirow{3}{*}{ Ethics } & $\begin{array}{l}\text { Between } \\
\text { groups }\end{array}$ & 825.640 & 3 & 275.213 & & & $\begin{array}{l}1-2 \\
1-3\end{array}$ \\
\hline & In groups & 7629.188 & 409 & 18.653 & 14.754 & $.000^{*}$ & $1-4$ \\
\hline & Total & 8454.828 & 412 & & & & $\begin{array}{l}2-3 \\
2-4\end{array}$ \\
\hline \multirow{3}{*}{ Proficiency } & $\begin{array}{l}\text { Between } \\
\text { groups }\end{array}$ & 1027.739 & 3 & 342.580 & & & $\begin{array}{l}1-2 \\
1-3\end{array}$ \\
\hline & In groups & 5560.648 & 409 & 13.596 & 25.198 & $.000 *$ & $1-4$ \\
\hline & Total & 6588.387 & 412 & & & & $\begin{array}{l}2-3 \\
2-4\end{array}$ \\
\hline
\end{tabular}

${ }^{*} \alpha=0.05 ; 1$ : Basic level 2: Intermediate level 3: Advanced level 4: Expert level

As seen in Table 9, there is a significant difference in the TPACK competencies of PSTs in terms of design, exertion, ethics and proficiency according to the PSTs' perception of their ability to use technology (Design $[\mathrm{F}=23.725$, $\mathrm{p}<=0.05]$; Exertion $[\mathrm{F}=21.827, \mathrm{p}<=0.05]$; Ethics $[\mathrm{F}=14.754, \mathrm{p}<=0.05]$; Proficiency $[\mathrm{F}=25.198, \mathrm{p}<=0,05])$. The findings of the Bonferroni test showed that TPACK competencies for design, exertion, ethics and proficiency of PSTs who perceive their technology use as being at an advanced or expert level are higher than PSTs who perceive their technology use as being at a basic or intermediate level. 
As a result, the ICT and TPACK competencies of PSTs differ according to grade, having one's own computer for educational purposes, and one's perceived ability to use technology, but do not differ by gender. It was observed that the ICT integration competencies of PSTs differ between those who attend fourth grade and the others, between those who own a computer for educational purposes and those who do not, between those who perceive their technology use as being at an advanced or expert level and the others.

\section{Discussion}

In the face of continually developing and changing technology, it is difficult to ascertain which competencies teachers and PSTs should have for ICT integration. Factors contributing to the explanation of the ICT integration process, skills and competencies, pedagogical beliefs and self-efficacy, professional development and teacher experiences, ICT infrastructure, access, and tools are seen to positively affect ICT use (Kaya \& Usluel, 2011). Teachers' perception of competencies and pedagogical knowledge regarding ICT integration is essential when starting to integrate ICT into teaching practices (Aslan \& Zu, 2015). In this study, the ICT integration competencies of PSTs were examined according to gender, grade, having one's own computer for educational purposes, and one's perceived ability to use technology. There is no significant difference in ICT competencies and TPACK competencies according to the gender of PSTs. This result is in line with the studies in the literature (Gömleksiz \& Fidan, 2013; Çoklar, 2014; Şad \& Nalçac1, 2015; Bakaç \& Özen, 2018). There is a significant difference in ICT competencies and TPACK competencies according to the grade of PSTs. This difference is in favour of the fourth grades. As the level of PSTs' grade increases, their levels of ICT integration competence increase.

According to computer ownership for educational purposes, there is a significant difference in terms of ICT competencies and TPACK competencies. This difference is in favour of PSTs who own computers. Studies show that teachers' ICT competence levels differ according to their computer ownership status (Şad \& Nalçac1, 2015). Also, studies demonstrate that teachers' TPACK levels change according to their ability to access technology (Özkara, Konokman, \& Yelken, 2018).

According to PSTs' perceived ability to use technology, there is a significant difference in ICT competencies and TPACK competencies. This difference is in favour of PSTs who think they can use technology at the advanced or expert level. As the PSTs experience an increase in their perceived level of skill in their use of technology, their ICT integration competencies increase. Samancioğlu and Summak (2014) state that technology usage in teachers' lessons depends on their computer usage skills. Özgen, Narl1 and Alkan (2013) found that PSTs' TPACK scores differ according to the frequency they perceive in technology use. Another study conducted with PSTs demonstrated that the TPACK 
competencies of the PSTs changed according to the ICT usage stages (adherence, comprehension, influence, and renewal) (Çoklar, 2014). For example, it was observed that a PST at the renewal stage had higher TPACK competence than the PSTs at the level of comprehension, and the ICT usage stages of PSTs were a predictive and important variable in TPACK competency. Şimşek and Yazar (2018) found that PSTs' technology knowledge self-efficacy is an important variable affecting technology integration. The ICT competencies and TPACK competencies of PSTs who perceive their abilities as proficient in terms of ICT use in this study are significantly different. This study shows that PSTs' computer ownership has a significant impact on their education; it enables them to improve their skills in the use of technology and is advantageous in terms of ICT integration competencies.

\section{Conclusion}

Teaching is a profession that requires continuous personal and professional development (Noga, 2016). There is a need for educational processes that emphasise technology's educational value and enable teachers to improve themselves pedagogically and plan more effective teaching-learning processes using this pedagogical knowledge. To meet the needs of the learners of this century, teachers must first be equipped with the necessary knowledge and skills in their educational processes (Y1ldirım, 2000; Zhou et al., 2010). PSTs should experience this process in their teaching-learning process, and should receive training in the integration of ICT in the teaching-learning process (Çubukçu et al., 2017). Research shows that the learning experiences of PSTs in this sense and the integration of ICT with their subject areas are closely related to understanding ICT's educational value (Mumcu \& Usluel, 2015). Academics who take a role in teacher education should use technology effectively in their lessons and PSTs should experience the educational uses of technology through their education (Başal, 2015). However, it has been observed that faculty members of colleges of education face some problems in their lectures such as a lack of technical infrastructure, a lack of technical knowledge, and problems arising from technical failures, and they try to find solutions such as asking stakeholders for help in dealing with these problems, using different technologies, or trying alternative methods (Keleş \& Güntepe, 2018). As a whole, teacher educators have substantial duties and should take a more active role in addressing this issue in teacher education programmes (McGarr \& Gallchoir, 2020). Inadequate attention is paid to initial teacher education in ICT competencies. It is thought that PSTs are knowledgeable about technology and this issue is handled effectively in their education. Therefore, there seems to be a belief that development in this area is less of a priority (McGarr \& McDonagh, 2020). Discussion of the competencies for ICT integration is closely related to the design and quality of learning opportunities to which PSTs are exposed during their teacher education programmes (European Commission, 2013). It is 


\section{Acta Educationis Generalis \\ Volume 11, 2021, Issue 2}

considered that there is a need for revising the course content and teaching processes within the framework of the competencies PSTs should have. In this context, it can be argued that while focusing on ICT integration competencies in teacher education, a more comprehensive understanding should be provided, and sustainable arrangements are needed to develop the ICT competencies and TPACK competencies of PSTs, which are essential factors in the ICT integration process.

\section{References}

Angeli, C., \& Valanides, N. (2009). Epistemological and methodological issues for the conceptualization, development, and assessment of ICT-TPCK: Advances in technological pedagogical content knowledge (TPCK). Computers \& Education, 52(1), 154-168.

Aslan, A., \& Zhu, C. (2015). Starting teachers' integration of ICT into their teaching practices in the lower secondary schools in Turkey. Educational Sciences: Theory \& Practice, 18(1), 2345.

Atalay, N., \& Anagün, Ş. S. (2014). The views of classroom teachers working in rural areas about using information and communication technologies. Journal of Qualitative Research in Education, 2(3), 9-27.

Bakaç, E., \& Özen, R. (2018). The relationship between preservice teachers' self-directed learning readiness levels and technological pedagogical content knowledge (TPACK) competencies. Education Sciences, 13, 90-105.

Başal, A. (2015). English language teachers and technology education. Journal of Theory and Practice in Education, 11, 1496-1511.

Becuwe, H., Roblin, N. P., Tondeur J., Thys J., Castelein E., \& Voogt J. (2017). Conditions for the successful implementation of teacher educator design teams for ICT integration: A delphi study. Australasian Journal of Educational Technology, 33(2), 159-172.

Birişçi, S., \& Kul, Ü. (2018). Investigation of technology integration self-efficacy beliefs of preservice teachers' who attend pedagogical formation training. Journal of Science, Mathematics, Entrepreneurship and Technology Education, 1,1-18.

Bozdağ, Ç. (2017). Technology integration in Turkish and German schools: A comparative analysis of eTwinning. Journal of Ege Education Technologies, 1, 42-64.

Büyüköztürk, Ş. (2002). Sosyal bilimler için veri analizi el kitabi. Ankara: Pegem Akademi Yayıncilik.

Çam, E., \& Saltan, F. (2019). The relationship between primary education teachers' technological pedagogical content knowledge and lifelong learning tendency. Elementary Education Online, 18, 1196-1207.

Çelik, İ., Hebebci, M. T., \& Şahin, İ. (2016). Role of use of online case study library in technology integration: A study based on TPACK. Gaziantep University Journal of Social Sciences, 15, 739-754.

Çrak, S., \& Demir, S. (2014). Examining classroom teachers' views about their competencies concerning the integration of technology. Gaziantep University Journal of Social Sciences, 13, 99-113.

Çil, E., \& Çakmak, G. (2014). The assessment of the competencies of technological pedagogical content knowledge of prospective teachers in terms of some variables. Turkish Journal of Educational Studies, 1, 140-170.

Çoklar, A. N. (2014). Primary school preservice teachers' technological pedagogical content knowledge competency in terms of gender and ICT use phase. Education and Science, 39, 319-330. 


\section{Acta Educationis Generalis \\ Volume 11, 2021, Issue 2}

Çubukçu, Z., Tosuntaş, Ş. B., İnci, T., \& Kırcaburun, K. (2017). Evaluation of instructional technology and material design course in terms of contribution to technology integration. Anatolian Journal of Educational Leadership and Instruction, 5, 29-41.

Cüre, F., \& Özdener, N. (2008). Teachers' information and communication technologies (ICT) using achievements and attitudes towards ICT. Hacettepe University Journal of Education, 34, 41-53.

Ersoy, M., Yurdakul, I. K., \& Ceylan, B. (2016). Investigating preservice teachers' TPACK competencies through the lenses of ICT skills: An experimental study. Education and Science, 41(186), 119-135.

Ertmer, P. A. (1999). Addressing first-and second-order barriers to change: Strategies for technology integration. Educational Technology Research and Development, 47(4), 47-61.

European Commission (2013). Supporting teacher competence development for better learning outcomes. Brussels: European Commission Education and Training UE.

Goktas, Y., Yildirim, S., \& Yildirim, Z. (2009). Main barriers and possible enablers of ICTs integration into pre-service teacher education programs. Educational Technology \& Society, 12(1), 193-204.

Gömleksiz, M. N. \& Fidan, E. K. (2013). Self-efficacy perception levels of prospective classroom teachers toward technological pedagogical content knowledge. Inonu University Journal of the Faculty of Education, 14, 87-113.

Güneş, A. M. \& Buluç, B. (2018). The relationship between classroom teachers' classroom management skills and technology use. Necatibey Faculty of Education Electronic Journal of Science and Mathematics Education, 12, 739-771.

Haşlaman, T., Mumcu, F., \& Usluel, Y. K. (2007). The integration of information and communication technologies in teaching-learning process: A lesson plan example. Education and Science, 32(146), 54-63.

Hatlevik, O. E., Guðmundsdóttir, G. B., \& Loi, M. (2015). Digital diversity among upper secondary students: a multilevel analysis of the relationship between cultural capital, selfefficacy, strategic use of information and digital competence. Computers \& Education, 81, 345-353.

International Society for Technology Education [ISTE] (2020). ISTE Standards Teachers. Retrieved from https://www.iste.org/docs/pdfs/20-14_ISTE_Standards-T_PDF.pdf

Kabakçı Yurdakul, I., Odabaşı, H. F., Kılıçer, K., Çoklar, A. N., Birinci, G., \& Kurt, A. A. (2012). The development, validity and reliability of TPACK-deep: A technological pedagogical content knowledge scale. Computers \& Education, 58(3), 964-977.

Kaya, G., \& Usluel, Y. K. (2011). Content analysis of factors affecting ICT integration in teaching-learning process. Buca Eğitim Fakültesi Dergisi, 31, 48-67.

Keleş, E., \& Güntepe, E. T. (2018). Technological integration into learning-teaching process of the instructors in the faculty of education. Sakarya University Journal of Education, 8,142-157.

Kozma, R. B. (2010). ICT policies and educational transformation. Retrieved from http://www.unesco.org/new/fileadmin/MULTIMEDIA/HQ/ED/ICT/pdf/ICTpoliedtran.pdf

Kurtoğlu, M., \& Seferoğlu, S. S. (2013). Examination of studies conducted on teachers' technology usage published in Turkish journals. Journal of Instructional Technologies \& Teacher Education, 2, 1-10.

McGarr, O., \& Gallchoir, C. O. (2020). Exploring pre-service teachers' justifications for one-toone technology use in schools: Implications for initial teacher education. Technology, Pedagogy and Education, 29(4), 477-490.

McGarr, O., \& McDonagh, A. (2020). Exploring the digital competence of pre-service teachers on entry onto an initial teacher education programme in Ireland. Irish Educational Studies, 40(1), 115-128. https://doi.org/10.1080/03323315.2020.1800501

Ministry of National Education [MoNE] (2017). Öğretmenlik mesleği genel yeterlikleri. Öğretmen Yetiştirme ve Geliştirme Genel Müdürlüğü, Ankara. Retrieved from https://oygm.meb. 


\section{Acta Educationis Generalis \\ Volume 11, 2021, Issue 2}

gov.tr/meb_iys_dosyalar/2017_12/11115355_YYRETMENLYK_MESLEYY_GENEL_YE TERLYKLERY.pdf

Mishra, P., \& Koehler, M. J. (2006). Technological pedagogical content knowledge: A new framework for teacher knowledge. Teachers College Record, 108(6), 1017-1054.

Mumcu, F., Uslu, N. A., \& Geriş, A. (2018). A study of adaptation of teacher candidates' ICT competence scale into Turkish. VIII. International Conference on Research in Education (ICRE 2018), May 9-11, Manisa, Turkey.

Mumcu, F. (2017). Preparedness of preservice teachers to integration of ICT into learning and teaching process: Change in knowledge and beliefs. Educational Technology Theory and Practice, 7(1), 31-56.

Mumcu, F., \& Usluel, Y. (2015). Designing a networked learning process about ICT integration for preservice teachers. Ankara University Journal of Faculty of Educational Sciences, 48(1), 19-47.

Mumcu, F. K., \& Usluel, Y. K. (2010). ICT in vocational and technical schools: Teachers' instructional, managerial and personal use matters. The Turkish Online Journal of Educational Technology (TOJET), 9(1), 98-106.

Nelson, M. J., \& Hawk, N. A. (2020). The impact of field experiences on prospective preservice teachers' technology integration beliefs and intentions. Teaching and Teacher Education, 89, $1-12$.

Noga, H. (2016). Professional development of information technology and technical education teachers. Acta Educationis Generalis, 6(2), 96-104. https://doi.org/10.1515/atd-2016-0015

Özgen, K., Narlı S., \& Alkan, H. (2013). An investigation of mathematics teacher trainees' technological pedagogical content knowledge and their perception of the frequency of technology use. Electronic Journal of Social Sciences, 12, 31-51.

Özkara, E. C., Konokman G. Y., \& Yelken, T. Y. (2018). The examination of teachers' selfconfidence on TPCK, participating in in-service education on "technology use in education" in the scope of FATIH Project. Amasya Education Journal, 7, 371-412.

Punie, Y. (Ed.), Redecker, C. (2017). European framework for the digital competence of educators: DigCompEdu. EUR 28775 EN. Luxembourg: Publications Office of the European Union, https://doi.org/10.2760/159770

Samancioğlu, M., \& Summak, M. S. (2014). Öğretmenlerin derslerde teknoloji kullanimlarini etkileyen faktörler: Kişisel bilgisayar kullanimi ve öğretim yaklaşimlari. Atatürk Üniversitesi Sosyal Bilimler Enstitüsü Dergisi, 18, 195-207.

Sarı, A. A., Bilici, S. C., Baran, E., \& Özbay, U. (2016). Investigating the relationship between teachers' technological pedagogical content knowledge (TPACK) competencies and attitudes towards information and communication technologies. Educational Technology Theory and Practice, 6, 1-21.

Şad, S. N., \& Nalçac1, Ö. İ. (2015). Prospective teachers' perceived competencies about integrating information and communication technologies into education. Mersin University Journal of the Faculty of Education, 11(1), 177-197.

Şahin, S. M., Yenmez, A. A., Özpınar, I., \& Köğce, D. (2013). Teacher candidates' views on the components of a pre-service training program based on the technological pedagogical content knowledge model. Hacettepe University Journal of Education, Special issue (1), 271-286.

Şimşek, Ö., \& Yazar, T. (2018). Analyzing technology integration self-efficacy of prospective teachers: The case of Turkey. Electronic Journal of Social Sciences, 17, 744-765.

Tondeur, J., Aesaert, K., Pynoo, B., van Braak, J., Fraeyman, N., \& Erstad, O. (2017). Developing a validated instrument to measure preservice teachers' ICT competencies: Meeting the demands of the 21st century. British Journal of Educational Technology, 48(2), 462-472.

Tosuntaş, Ş. B., Çubukçu, Z., \& İnci, T. (2019). A holistic view to barriers to technology integration in education. Turkish Online Journal of Qualitative Inquiry (TOJQI), 10, 439461. 


\section{Acta Educationis Generalis \\ Volume 11, 2021, Issue 2}

Uslu, N. A., \& Usluel, Y. (2020). Predicting technology integration based on a conceptual framework for ICT use in education. Technology Pedagogy and Education, 28, 517-531.

Usluel, Y. K., Mumcu, F., \& Demiraslan, Y. (2007). ICT in the learning-teaching process: Teachers' views on the integration and obstacles. Hacettepe University Journal of Education, 32, 164-178.

Usluel, Y. K., Özmen, B., \& Çelen, F. K. (2015). Integration of ICT in learning and teaching process and a critical overview of TPACK model. Educational Technology Theory and Practice, 5, 34-54.

Yildırım, S. (2000). Effects of an educational computing course on preservice and in-service teachers: A discussion and analysis of attitudes and use. Journal of Research on Computing in Education, 32(4), 479-495.

The Higher Education Council [HEC] (2018). Eğitim fakültelerinde uygulanacak yeni programlar hakkında açıklama. Retrieved from https://www.yok.gov.tr/Sayfalar/Haberler/ogretmenyetistirme-lisans-programlari.aspx

Zhou, Q., Zhao, Y., Hu, J., Liu, Y., \& Xing, L. (2010). Pre-service chemistry teachers' attitude toward ICT in Xian. Procedia Social and Behavioral Sciences, 9, 1407-1414. 